\title{
ACTIVE LEARNING IN E-LEARNING: ADVANCING A SYSTEMIC MODEL
}

\author{
Alex Koohang, Macon State College, Georgia, USA, alex.koohang@maconstate.edu
}

\begin{abstract}
This paper advances a systemic model for active learning in e-learning that builds on a string of previous research. The model consists of three stages (the underpinning, the ownership, and the engaging) internal/direct to learning and prerequisite elements (class size; active \& responsive support services; standard course policies; and elearning courseware usability) external/indirect to learning. The model is systemic because the three stages and the prerequisite elements are interrelated to each other and together influence the "learning" in e-learning.
\end{abstract}

Keywords: Active learning, constructivism, e-learning, learning

\section{INTRODUCTION}

E-learning, also referred to as "distance education" or "online education", is defined as "... the delivery of education (all activities relevant to instructing, teaching, and learning) through various electronic media." [16].

Allen and Seaman [3] reported that there are over 6 million students taking at least one online course in the United States. Specifically, they reported the following:

- $\quad$ The $10 \%$ growth rate for online enrollments far exceeds the $2 \%$ growth in the overall higher education student population.

- Thirty-one percent of higher education students now take at least one course online.

- Reported year-to-year enrollment changes for fully online programs by discipline show most are growing.

- $65 \%$ of higher education institutions now say that online learning is a critical part of their long-term strategy.

- Academic leaders believe that the level of student satisfaction is equivalent for online and face-to-face courses. " [3]

With the proliferation of online education, 'learning' in e-learning settings becomes a significant challenge. Higher education institutions and professors teaching online courses must take every measure to ensure learning in elearning. The purpose of this paper is to present a systemic model for active learning in e-learning that ensures learning in e-learning settings. Consistent with its purpose, this paper begins with an introduction to e-learning and its impact on higher education. It will then explain what active learning entails. Next, the paper makes a link between active learning and constructivism learning theory. Building on a string of previous research, the paper builds the case for advancing a systemic model for active learning in e-learning.

\section{WHAT IS ACTIVE LEARNING?}

E-learning demands learning to be active and focus on the construction of knowledge by continuously engaging students in active learning $[15,16]$. Active learning is the process of actively engaging learners in higher-order thinking to construct knowledge. Active learning is about learners "doing things" and "thinking about the things they are doing" [5, iii]. With active learning, learners are able to analyze, synthesize, and evaluate complex problems [5]. An active learning environment is learner-centered. This means that emphasis is on advancing learners' skills [5] and learners' knowledge construction [15]. Good active learning focuses on applying content; it should be engaging and technology friendly. Active learning must have meaningful learning with interesting instructional materials that encourages engaged collaboration [10]. 


\section{Issues in Information Systems}

Volume 13, Issue 1, pp. 68-76, 2012

\section{ACTIVE LEARNING AND CONSTRUCTIVISM}

Active learning takes place through the elements of constructivism learning theory. Constructivism learning theory is rooted in the scholarly research by Dewey [7], Piaget [21], Vygotsky [22], Ausubel [4], Bruner [6], Ernest [8], Honebein [9], and Jonassen [10, 11]. Constructivism learning theory underlines construction of new knowledge based on a number of characterizations/elements. Based on a thorough review of the literature, Murphy [18] synthesized a list of characteristics inherent to constructivism. These characteristics are summarized and shown in Table 1.

Table1: Constructivism Characteristics \& Elements

\begin{tabular}{|c|c|}
\hline $\begin{array}{l}\text { Murphy's Synth } \\
\text { Characteristics }\end{array}$ & $\begin{array}{l}\text { Koohang's Categorization of Const } \\
\text { Elements }\end{array}$ \\
\hline $\begin{array}{ll}\text { - } & \text { Apprenticeship learning } \\
\text { - } & \text { Collaborative learning } \\
\text { - } & \text { Control of own learning. } \\
\text { - } & \text { Cooperative learning } \\
\text { - } & \text { Errors provide the opportunity for insight into } \\
\text { - } & \text { students' previous knowledge constructions. } \\
\text { - } & \text { Higher-order thinking skills } \\
\text { - } & \text { Instructors are guides, monitors, coaches, tutors } \\
\text { - } & \text { Ind facilitators } \\
\text { - } & \text { Interrelatedness } \\
\text { - } & \text { Knowledge construction } \\
\text { - } & \text { Mearner-driven goals and objectives } \\
\text { - } & \text { Multiple perspectives } \\
\text { - } & \text { Primary sources of data } \\
\text { - } & \text { Reblem-solving } \\
\text { - } & \text { Scafforlding problems } \\
\text { - } & \text { Self reflection } \\
\text { - } & \text { Self-analysis } \\
\text { - } & \text { Self-awareness } \\
\text { - } & \text { Self-regulating } \\
\text { - Social negotion } & \text { experience }\end{array}$ & $\begin{array}{l}\text { "Elements of Constructivism - The Design of } \\
\text { Learning Activities } \\
\text { - } \quad \text { Collaboration } \\
\text { - } \quad \text { Conceptual interrelatedness and } \\
\text { - } \quad \text { interdisciplinary learning } \\
\text { - } \quad \text { Exploration } \\
\text { - } \quad \text { Learner control of learning } \\
\text { - } \quad \text { Learner self-mediating of learning } \\
\text { - } \quad \text { Learners' belief and attitude } \\
\text { - } \quad \text { Learners' own previous experience } \\
\text { - } \quad \text { Multiple perspectives } \\
\text { - } \quad \text { Multiple representations of } \\
\text { - } \quad \text { Primary source of data } \\
\text { - } \quad \text { Problem solving } \\
\text { - } \quad \text { Real world examples } \\
\text { - } \quad \text { Scaffolding } \\
\text { - } \quad \text { Self-reflection } \\
\text { - } \quad \text { Social negotiation } \\
\text { Elements of Constructivism - Learning } \\
\text { Assessment } \\
\text { - Collaborative assessment - Team } \\
\text { - Instructor assessment } \\
\text { - } \quad \text { Self-assessment - Individual } \\
\text { Elements of Constructivism - Instructor's Roles } \\
\text { - } \quad \text { Acknowledging } \\
\text { - } \quad \text { Assessment student learning } \\
\text { - } \quad \text { Guaching } \\
\text { - } \quad \text { Mentoring } \\
\text { Providing Feedback" [15] }\end{array}$ \\
\hline
\end{tabular}




\section{Issues in Information Systems}

Volume 13, Issue 1, pp. 68-76, 2012

Koohang [15], in designing a learner-centered model, referred to these characteristics as elements of constructivism and grouped them into three categories - the design of learning activities, learning assessment, and the instructor roles. See Table 1 for elements of constructivism in each category. This model was modified in a later research to show a learner-centered model for designing e-learning assignments and activities for e-learning. The model included two categories, namely, the learning design elements and the learning assessment [17]. Building upon these two models, the present study advances a systemic model for active learning in e-learning that fine tunes the previous models and introduces an additional part in the model, i.e., external/indirect elements, crucial to the success of learning in e-learning.

\section{THE SYSTEMIC MODEL FOR ACTIVE LEARNING IN E-LEARNING}

Figure 1 illustrates the systemic model for active learning in e-learning. The model is comprised of three stages that are internal/direct to learning (the underpinning, the ownership, and the engaging). In addition, the model relies on prerequisite elements (class size; active \& responsive support services; standard course policies; and e-learning courseware usability) that are external/indirect to learning. The model is systemic because all stages and the prerequisite elements of the model relate to and affect the entire process of learning. This means that three stages and the prerequisite elements must, in their entirety, be present in e-learning environment for successful learning to occur.

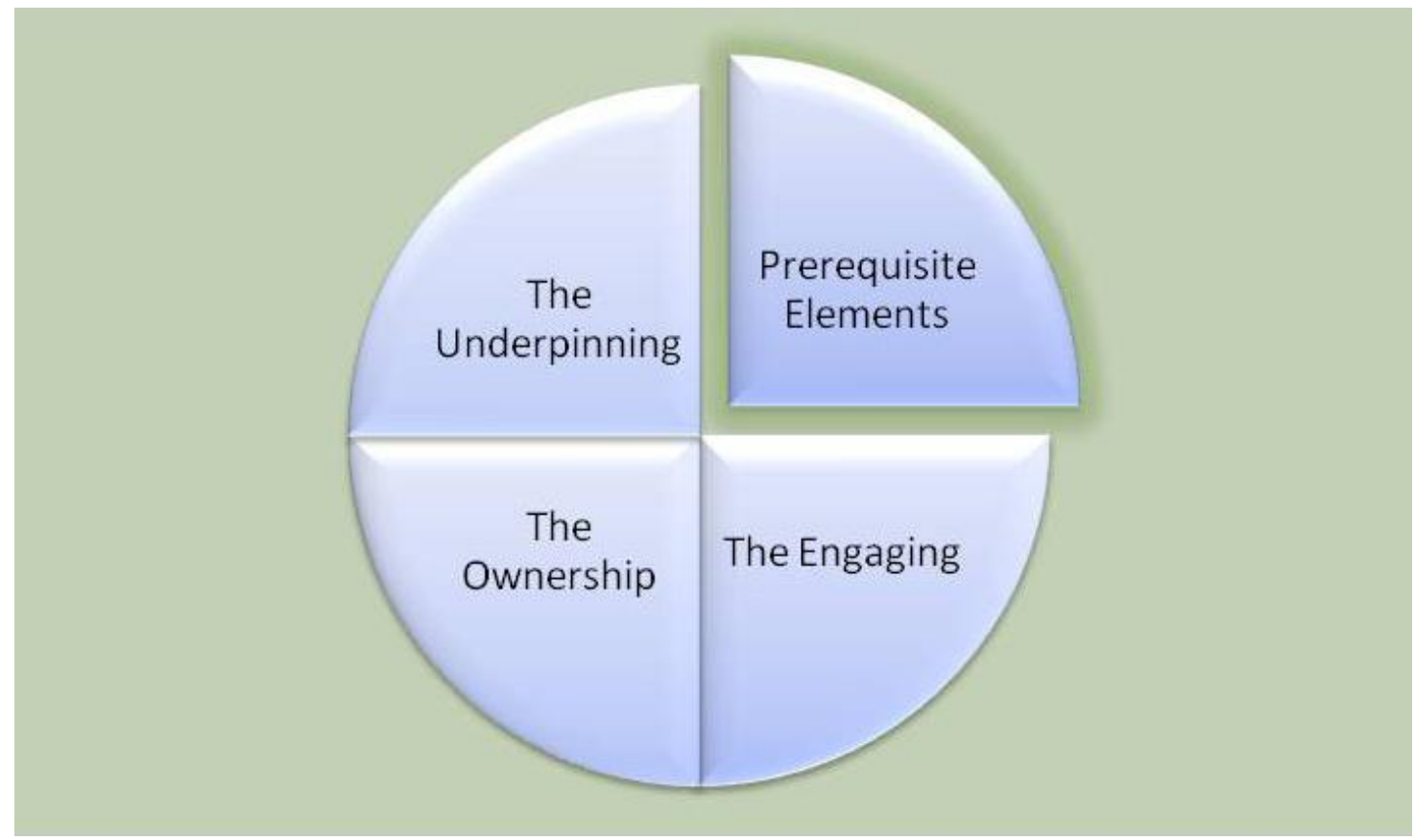

Figure 1: A Systemic Model for Active Learning in E-Learning

\section{Active Learning in E-Learning: The Three Stages}

Table 2 shows a summary of the active learning stages' elements (the underpinning, the ownership, and the engaging). It includes the active learning elements, the learner's role and responsibilities, and the instructor's role and responsibilities for each stage. 


\section{Issues in Information Systems}

Volume 13, Issue 1, pp. 68-76, 2012

Table 2: Active Learning Elements with Learner/Instructor Roles \& Responsibilities

\begin{tabular}{|c|c|c|c|}
\hline Stages & Active Learning Elements & $\begin{array}{l}\text { Learner } \\
\text { (Role and Responsibilities) }\end{array}$ & $\begin{array}{l}\text { Instructor } \\
\text { (Role and Responsibilities) }\end{array}$ \\
\hline Underpinning & $\begin{array}{ll}\text { - } & \text { Real world and relevant } \\
\text { examples } \\
\text { - } & \text { Exploration } \\
\text { - } & \text { Higher-order thinking } \\
\text { skills (Analysis, } \\
\text { evaluation, \& synthesis) } \\
\text { - Scaffolding that can be } \\
\text { used to make learners } \\
\text { think above and beyond } \\
\text { what they normally } \\
\text { know }\end{array}$ & & $\begin{array}{l}\text { Designing into all } \\
\text { course activities } \\
\text { immediately to guide } \\
\text { learners to become } \\
\text { active learners and } \\
\text { initiate deep learning }\end{array}$ \\
\hline Ownership & $\begin{array}{ll}\text { - } & \text { Learner's driven goals } \\
& \text { and objectives } \\
\text { - } & \text { Learner's self-mediating } \\
& \text { and control of learning } \\
\text { - } & \text { Learner's self-reflection } \\
\text { - } & \text { Learner's self-awareness } \\
\text { - } & \text { Learner's own } \\
& \text { experience } \\
\text { - } & \text { Learner's self- } \\
& \text { assessment } \\
\text { - } \quad \text { Learner's own } \\
\text { representation of ideas } \\
\text { and/or concepts } \\
\end{array}$ & $\begin{array}{ll}\text { - } & \text { Setting own goals \& } \\
& \text { objectives } \\
\text { - } & \text { Taking control of } \\
& \text { learning } \\
\text { - } & \text { Reflecting } \\
\text { - } & \text { Being aware of } \\
& \text { learning } \\
\text { - } & \text { Including own } \\
& \text { experiences } \\
\text { - } & \text { Self-assessing } \\
\text { - } & \text { Presenting ideas } \\
& \text { and/or concepts }\end{array}$ & $\begin{array}{l}\text { Designing into all } \\
\text { course activities } \\
\text { immediately to guide } \\
\text { learners to become } \\
\text { active learners by } \\
\text { participating in the } \\
\text { ownership of learning } \\
\text { Actively } \\
\text { communicating }\end{array}$ \\
\hline Engaging & $\begin{array}{l}\text { Learners' active } \\
\text { engagement in analysis, } \\
\text { evaluation, \& synthesis } \\
\text { of multiple perspectives } \\
\text { - Learners' collaborative } \\
\text { assessment }\end{array}$ & $\begin{array}{l}\text { - } \begin{array}{l}\text { Actively creating } \\
\text { knowledge }\end{array} \\
\text {. }\end{array}$ & $\begin{array}{l}\text { Actively coaching, } \\
\text { guiding, mentoring, } \\
\text { tutoring, \& facilitating } \\
\text { Actively providing } \\
\text { feedback } \\
\text { - Actively assessing } \\
\text { - Actively } \\
\text { communicating }\end{array}$ \\
\hline
\end{tabular}

\section{Active Learning Stage 1: The Underpinning}

The underpinning stage creates the bedrock, the basis, the backbone, the foundation, and the groundwork for learning. It is the nucleus of learning. It reinforces and supports learning at all stages. The elements of this stage are:

1. Real world and relevant examples

2. Exploration

3. Higher-order thinking skills - analysis, evaluation, \& synthesis

4. Scaffolding that can be used to make learners think above and beyond what they normally know

The instructor builds and designs these elements into course activities, assignments, and/or projects. These elements set the environment for learners to become active learners. They initiate the learning process. 


\section{Issues in Information Systems}

Volume 13, Issue 1, pp. 68-76, 2012

\section{Active Learning Stage 2: The Ownership}

The ownership stage gives identity to each learner to influence, grasp, and lead his/her own learning. It promotes learner's self-confidence and power to begin and take control of learning. The elements of this stage are:

1. Learner's driven goals and objectives

2. Learner's self-mediating and control of learning

3. Learner's self-reflection

4. Learner's self-awareness

5. Learner's own experience

6. Learner's self-assessment

7. Learner's own representation of ideas and/or concepts

The instructor builds and designs these elements into course activities, assignments, and/or projects. These elements build upon the elements in the underpinning stage to guide the learner to actively participate in the ownership of learning. The learners set their own goals/objectives and take control of learning. The activities, assignments, and/or projects must allow for self-reflection and self-awareness. Learners include their own individual experiences in solving case-based activities. They are responsible for self-assessment and individual presentation of ideas and/or concepts.

\section{Active Learning Stage 3: The Engaging}

The engaging stage actively builds a community of learners that interact, negotiate, arbitrate, compromise, debate, discuss, mediate, acknowledge, approve, confirm, stipulate, inquire, exchange, interpret, persuade, and present perspectives to create new knowledge. The elements of this stage are:

1. Learners' active engagement in analysis, evaluation, \& synthesis of multiple perspectives

2. Learners' collaborative assessment

The instructor builds and designs these elements into course activities, assignments, and/or projects. These elements build upon the elements in the ownership stage to create a community of learners that collaboratively and actively engage in the construction of new knowledge. The instructor's responsibility is not merely facilitating the learning process. The instructor actively coaches, guides, mentors, tutors, assesses, and provides feedback to learners.

\section{Active Learning: The Prerequisite Elements}

The prerequisite elements are external/indirect to the learning process. These elements 1) class size, 2) active \& responsive support services, 3) standard course policies, and 4) e-learning courseware usability. They are beyond the underpinning, the ownership, and the engaging stages where learners actively create new knowledge. These prerequisite elements are essential requirements that relate to and affect the learning process in e-learning environments.

\section{Class Size}

Previous literature has documented that in a traditional face-to-face course, smaller class size yield to increased student learning achievement [1,2]. The literature likewise documents that class size in online courses (generally 15 to 20 students) leads into producing meaningful knowledge that contributes positively to student learning [20].

In the proposed model for active learning in e-learning, class size is a significant prerequisite element. The construction of knowledge requires a systemic interconnected approach that includes all the elements in the underpinning, ownership, and engaging stages. In particular, the engaging stage demands building an active community of learners that constantly interact, negotiate, arbitrate, compromise, consult, debate, discuss, mediate, 


\section{Issues in Information Systems}

Volume 13, Issue 1, pp. 68-76, 2012

acknowledge, approve, confirm, stipulate, inquire, persuade, reconcile, exchange, interpret, and present perspectives to create new knowledge. Therefore, a large class size does not allow for the construction of meaningful knowledge. For learning to occur successfully in e-learning, an online class should be 15 to 20 students for undergraduate courses and 10 to 15 students for graduate courses.

\section{Active \& Responsive Support Services}

Active and responsive support services are critical to the success of the model. The tasks are normally performed by the e-learning system administration team. The team consists of the e-leaning system administrator, the e-learning instructional designer(s), and the support specialists. The overall responsibility of this group is to maintain the elearning system's integrity, functionality, 24/7 availability, and accessibility. The instructional designer is responsible for providing on-going training and support to the instructors. In addition, the instructional designer must assess instructional technology needs and develop and implement the appropriate solutions to address these needs. The support specialists continuously accommodate a wide variety of needs that students and instructors may have. These needs are providing online training, online tutorials, providing specialized support for learners with disabilities among others.

The active and responsive support services can result in a culture that maintains a positive, helpful, and constructive relationship with students and instructors, thus contributing to the overall success of learning.

\section{Standard Course Policies}

Setting the standard policies for online courses are crucial in the success of learning in the model. A set of thorough and clear course policies included in the syllabus can keep the learner on-task and contribute to the success of learning. Course policies must include the following:

- A clear definition of how the course will be delivered (asynchronous, synchronous) and whether the curse requires additional software and/or hardware

- An explanation of the courseware platform(s) - where learning takes place

- A statement of student responsibility that includes exhibition of motivation, discipline, and commitment to learning

- A clear explanation for due dates for completing individual/group activities/assignments/projects

- A clear definition of active learning and learners' expectations in course engagement - individually and in team

- A clear guideline for online discussions and online team collaboration

- A clear explanation of how learners can access the professor

- A clear explanation of how the learner can access the support services

- A clear explanation of the purpose and structure of the course

- A clear explanation of the measurable learning outcomes

- A clear explanation of the learner's assessments

- A clear explanation of the methods of routine and regular communication between the professor and students and among students

\section{E-Learning Courseware Usability}

E-learning courseware usability is a crucial element in the success learning in the model. In general, Nielsen [19] defines usability by five quality components. They are "1) Learnability: How easy is it for users to accomplish basic tasks the first time they encounter the design?; 2) Efficiency: Once users have learned the design, how quickly can they perform tasks?; 3) Memorability: When users return to the design after a period of not using it, how easily can they reestablish proficiency?; 4) Errors: How many errors do users make, how severe are these errors, and how easily can they recover from the errors?; and 5) Satisfaction: How pleasant is it to use the design?" [19] 


\section{Issues in Information Systems}

Volume 13, Issue 1, pp. 68-76, 2012

The e-learning courseware usability has been the focus of the literature $[13,14]$. The consensus is that learning in elearning depends upon the usability of e-learning design. In particular, Koohang [14] summarized and outlined eighteen properties of usability for e-learning courseware design. These usability properties, adapted and modified from Koohang [14] are shown in Table 3, are put into four categories: the fundamental properties, the appearance properties, the information presentation properties, and the communication properties. The design of these usability properties in e-learning courseware is essential because they can result in improvement of usability quality components of learnability, efficiency, memorability, errors, and satisfaction, thus contributing to the entire learning process.

Table 3: The E-learning Courseware Usability Properties The Fundamentals

- Simplicity: The e-learning courseware is uncomplicated, simple, and straightforward.

- Comfort: The learner is comfortable using the e-learning courseware.

- User-friendliness: The e-learning courseware is easy to use.

- Control: The learner is in control throughout the e-learning courseware.

- Navigability: The learner can easily get to where I want to go throughout the e-learning courseware.

- Load/access time: The learner doesn't have to wait a long time for the pages to load.

- Recognition: The learner quickly recognizes the key points presented throughout the elearning courseware.

Appearance

- Link Visibility: The links throughout the e-learning courseware are visible.

- High color contrast: The color contrast of the text is high.

- Appropriate font type and size: The type and size of the fonts used to present information are appropriate.

- Visual Presentation: The visual presentation such as text boldfacing, italicizing, and underlining exist.

Information Presentation

- Well- organized: The information in every page is well-organized and structured.

- Adequacy/Task Match: The information presented is enough. It is no more/no less than what the learner needs to know.

- Readability: The learner has no problem understanding the language used to present information.

- Relevancy: The information presented is relevant to what the learner is supposed to know and learn.

- Right to the point information: The information is concise and right to the point.

- Consistency: There is consistency of appearance, terms, words, and action throughout the elearning courseware.

Communication

- Feedback: The e-learning courseware provides feedback.

- Direction: Directions on operating the e-learning courseware are available when the learner needs them.

Source: Adapted and modified from Koohang (2004) 


\section{Issues in Information Systems}

Volume 13, Issue 1, pp. 68-76, 2012

\section{CONCLUSION}

Active learning is the constant construction of new knowledge. Active learning creates a learning environment that insists on reinforcing higher-order thinking skills, exploration, and scaffolding based on raw data and real-world problems. It requires learners to actively and continuously participate in the ownership of their learning. Active learning gives learners the opportunity to create knowledge in the course of social negotiation.

Building upon previous research, this paper introduced a systemic model for active learning in e-learning that consists of three stages -- the underpinning stage, the ownership stage, and the engaging stage (internal/direct to learning) and four prerequisite elements -- class size, active \& responsive support services, standard course policies, and e-learning courseware usability (external/indirect to learning). The underpinning stage is the nucleus of learning that reinforces and supports learning at all stages. The ownership stage gives identity to each learner to influence and control of his/her own learning. The engaging stage actively reinforces building a community of learners to construct knowledge. The prerequisite elements of class size, active \& responsive support services, standard course policies, and e-learning courseware relate to and affect the learning process in e-learning environments. The model is systemic because all stages and the prerequisite elements of the model work together in their entirety to create successful learning in e-learning.

This model stipulates that both students and professors are open minded, self-motivated, self-disciplined, and exhibit a high level of commitment toward learning. The model rejects any inclusion of quizzes, tests, and/or examinations as they are detrimental to learning in active learning environments. Instead, the model mandates only inclusion and use of case-based (form simple to complex) assignments, activities, and/or projects.

\section{REFERENCES}

1. Abrami, P.C., Lou, Y., Chambers, B., Poulsen, C., and Spence, J.C. Why should we group students within-class for learning? Educational Research and Evaluation. 2: 158-179. 2000.

2. Achilles, C., Finn, J., and Bain, H. (1988). Using class size to reduce the equity gap. Educational Leadership. 55, 40-43.

3. Allen, E. \& Seaman, J. (2011). Going the distance: Online education in the United States, 2011. February 29, 2012 from http://sloanconsortium.org/publications/survey/going_distance_2011

4. Ausubel, D. Educational psychology: A cognitive view. New York: Holt, Rinehart \& Winston, 1968.

5. Bonwell, C., \& Eison, J. (1991). Active learning: Creating excitement in the classroom. Washington, DC: ASHE-ERIC Higher Education Report No. 1.

6. Bruner, J. (1990). Acts of Meaning. Cambridge, MA: Harvard University Press.

7. Dewey, J. (1933/1998) How we think (Rev. ed.). Boston, MA: Houghton Mifflin Company.

8. Ernest, P. (1995). The one and the many. In L. Steffe \& J. Gale (Eds.). Constructivism in education (pp.459486). New Jersey: Lawrence Erlbaum Associates, Inc.

9. Honebein, P. (1996). Seven goals for the design of Constructivist learning environments. In B. Wilson, Constructivist learning environments, pp. 17-24. New Jersey: Educational Technology Publications.

10. Johnson, P. A. (2011). Actively pursuing knowledge in the college classroom. Journal of College Teaching \& Learning, 8(6), 17-30.

11. Jonassen, D. (1991). Evaluating Constructivist Learning. Educational Technology, 36(9), 28-33.

12. Jonassen, D. (1994). Thinking technology. Educational Technology, 34(4), 34-37.

13. Koohang, A. \& du Plessis, J. (2004). Architecting usability properties in the e-learning instructional design process. International Journal on E-Learning, 3(3), 38-44.

14. Koohang, A. (2004). Expanding the concept of usability. Informing Science Journal, 7, 129-141.

15. Koohang, A. (2009). A learner-centered model for blended learning design. International Journal of Innovation and Learning, 6(1), 76-91.

16. Koohang, A., \& Harman, K. (2005). Open source: A metaphor for e-learning. Informing Science Journal, 8, 7586. 


\section{Issues in Information Systems}

Volume 13, Issue 1, pp. 68-76, 2012

17. Koohang, A., Riley, L., Smith, T. \& Schreurs, J. (2009). E-Learning and Constructivism: From Theory to Application, Interdisciplinary Journal of E-Learning \& Learning Objects, 5(1), 91-109.

18. Murphy, E. (1997). Constructivism: From philosophy to practice. February 29, 2012 from http://www.ucs.mun.ca/ emurphy/stemnet/cle3.html

19. Nielsen, J. (n.d.) Usability 101: Introduction to Usability. Retrieved February 29, 2012 from http://www.useit.com/alertbox/20030825.html

20. Palloff, R. \& Pratt, K. (1999). Building Learning Communities in Cyberspace. San Francisco: Jossey-Bass Publishers

21. Piaget, J. (1972). The psychology of the child. New York: Basic Books.

22. Vygotsky, L. (1978). Mind in society. Cambridge, MA: Harvard University Press. 